\title{
The biological role of epithelial-mesenchymal transition in lung cancer (Review)
}

\author{
WOO JUNG SUNG ${ }^{1}$, HONGTAE KIM ${ }^{2}$ and KWAN-KYU PARK ${ }^{1}$ \\ Departments of ${ }^{1}$ Pathology and ${ }^{2}$ Anatomy, Catholic University of Daegu College of Medicine, \\ Nam-gu, Daegu 42472, Republic of Korea
}

Received February 16, 2016; Accepted March 22, 2016

DOI: 10.3892/or.2016.4964

\begin{abstract}
Epithelial-mesenchymal transition (EMT) is a process whereby epithelial cells gradually transform into mesenchymal-like cells losing their epithelial functionality and characteristics. EMT is thought to be involved in the pathogenesis of numerous lung diseases ranging from developmental disorders and fibrotic tissue remodeling to lung cancer. Lung cancer is the most lethal form of cancer worldwide, and despite significant therapeutic improvements, the patient survival rate still remains low. Activation of EMT endows invasive and metastatic properties upon cancer cells that favor successful colonization of distal target organs. The present review provides a brief insight into the mechanism and biological assessment methods of EMT in lung cancer and summarizes the recent literature highlighting the controversial experimental data and conclusions.
\end{abstract}

\section{Contents}

1. Introduction

2. Tumor microenvironment and stem cells

3. Chemical mediators and transcription factors in EMT

4. Epigenetics and regulatory transcription factors

5. Invasion and metastasis

6. Future target therapy and conclusion

\section{Introduction}

Epithelial-mesenchymal transition (EMT) is a process whereby epithelial cells gradually acquire a mesenchymal cell

Correspondence to: Dr Kwan-Kyu Park, Department of Pathology, Catholic University of Daegu College of Medicine, 33 Duryugongwon-ro 17-gil, Nam-gu, Daegu 42472, Republic of Korea

E-mail:kkpark@cu.ac.kr

Key words: lung cancer, epithelial-mesenchymal transition, cancer stem cells, tumor microenvironment, transcription factors, epigenetics phenotype. EMT is associated with cancer progression, and is involved in its metastasis and treatment resistance as well as embryonic development and inflammatory process $(1,2)$. During EMT, cells lose their epithelial proteins and acquire mesenchymal proteins (3). This transition allows cancer cells to gain the ability to pass through the basement membrane and achieve increased invasive ability (4-6).

Through the process of EMT, cancer cells not only lose their cell-cell adhesion of epithelial phenotype and exhibit elevated motility and invasion, but also gain increased resistance to chemotherapeutic drugs (1). In addition, activation of EMT leads to the generation of cancer cells with stem cell-like characteristics (7-10). Therefore, cancer cells undergoing EMT may become drug-resistant cancer cell progenitors, or cancer stem cells (CSCs) (11). Pulmonary stem cells were first identified at the bronchioalveolar duct junction and these cells were termed bronchioalveolar stem cells (12). In recent years, lung CSC research has gained considerable momentum for both basic and clinical applications (11).

The present review provides an overview of the EMT of lung cancer in regards to the tumor microenvironment, CSCs, related cytokines or chemical mediators, related transcription factors, EMT epigenetics, invasion/metastasis and putative therapeutic applications.

\section{Tumor microenvironment and stem cells}

Inflammation in the lung microenvironment contributes to tumor initiation and invasion, promoting cancer cell EMT through its ability to induce the downregulation of epithelial cell proteins and upregulation of mesenchymal cell proteins $(13,14)$. The continuous and bilateral crosstalk, which occurs in the tumor microenvironment, is mediated by molecules secreted by either tumor or microenvironment stromal cells (15). This crosstalk of inflammatory mediators between tumors and their stroma results in tumor cell invasion, angiogenesis and metastasis (16).

Hypoxia is an essential characteristic of the tumor microenvironment (17). It promotes the developing tumor microenvironment through activation of NF- $\kappa \mathrm{B}$ signaling in macrophages, neutrophils and stromal cells $(18,19)$. Increased expression of hypoxia-related proteins are found in the central necrotic regions and the invading front of the tumor $(20,21)$. The hypoxic microenvironment has emerged as an important 


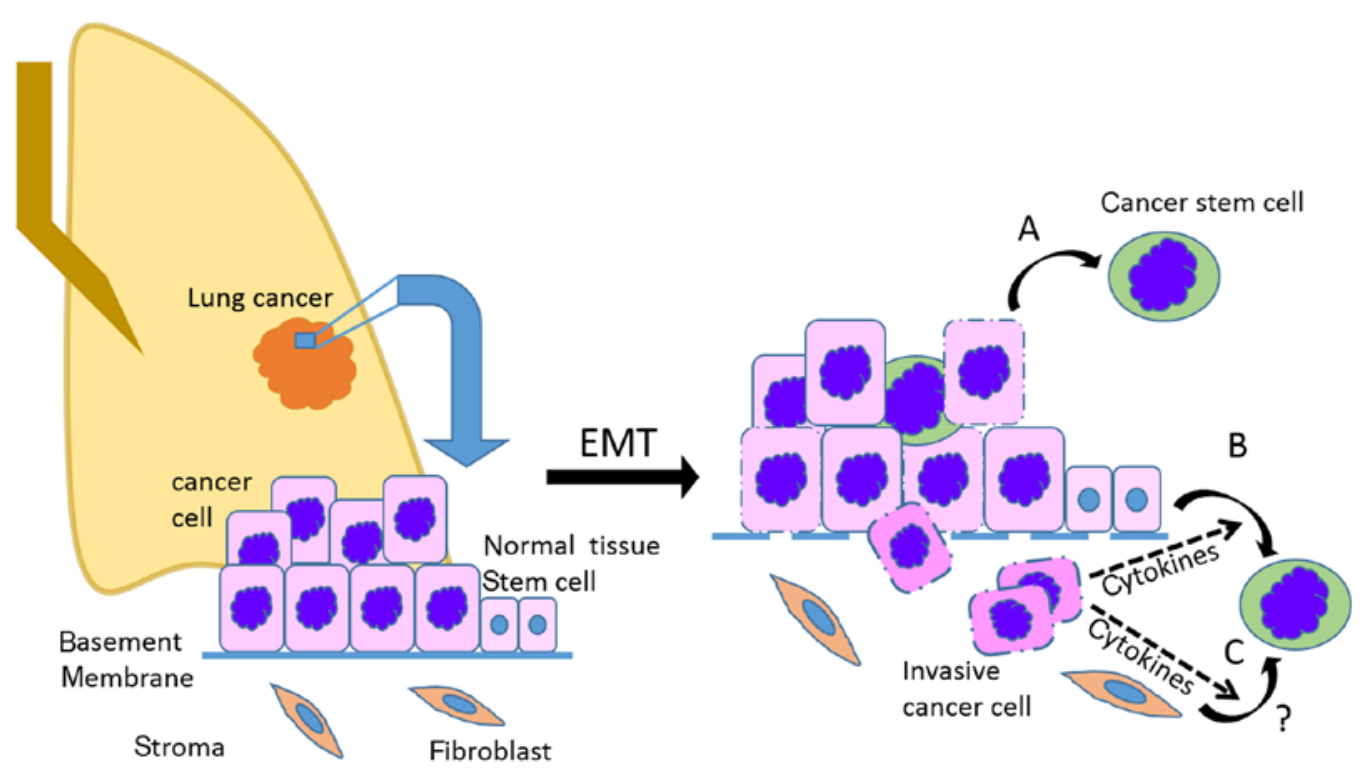

Figure 1. Cancer stem cell model. (A) Various cancer cells within the clonal tumor cell population are altered to cancer stem cells. (B) Malignant conversion of normal tissue stem cells into cancer stem cells via induction of EMT occurs in the tumor environment. (C) Fibroblasts in the tumor microenvironment are altered to cancer stem cells.

factor in the induction of EMT (17), and is associated with loss of epithelial gene expression, such as E-cadherin and induction of mesenchymal gene expression, such as fibronectin and collagen.

Carcinoma-associated fibroblasts (CAFs) are known as major components of the tumor microenvironment and are involved in cancer cell growth and survival, including angiogenesis and invasion (17). CAFs in the tumor microenvironment are present at the invasive front of the tumor (17). The conversion of fibroblasts into CAFs is driven by cancer cell-derived cytokines, such as transforming growth factor- $\beta 1$ (TGF- $\beta 1$ ) (15). CAFs produce extracellular matrix molecules and growth factors, including TGF- $\beta$, FGF2 and VEGF, leading to a conversion from a normal to a cancer-supporting microenvironment, a process known as tumor stromatogenesis (22). Bonde et al (23) reported that analysis of non-small cell lung cancer revealed a positive correlation between intratumoral CAF densities, EMT markers, intraepithelial TGF- $\beta$ levels and tumor grade.

Numerous components of the tumor microenvironment have been associated with CSCs and carcinogenesis, suggesting that the developing tumor microenvironment drives expansion and possible malignant conversion of normal tissue stem cells into CSCs via induction of EMT (Fig. 1). The precise origin of lung CSCs still remains to be resolved, but the term CSCs refers to tumorigenic cells with the ability to self-renew and to generate the diverse cell types present within the tumor $(24,25)$. Since most tumors are clonal in origin, tumorigenic CSCs must have the ability to give rise to a phenotypically diverse progeny (24) resulting in different degrees of proliferation, differentiation and invasiveness $(26,27)$. It has been revealed that normal tissue stem cells and CSCs share several stem cell-associated characteristics, such as the expression of primitive stem cell markers (28).

The employment of stem cell markers remains the most widely used approach for identifying lung CSCs (11). The markers currently used to isolate lung CSCs, are CD44, CD24, CD133 and ALDH (28-30). CD44 plays an important role in tumor cells undergoing an EMT-like process and is associated with cancer progression $(31,32)$. CD44-positive NSCLC cells were shown to be enriched in CSCs and resistant to cisplatin treatment (33). Sullivan et al (30) discovered that ALDH selects for a subpopulation of self-renewing NSCLC stemlike cells with increased tumorigenic potential, and NSCLC patients with ALDH1 tumor cells were found to have a worse prognosis (17). Since a single definite lung CSC marker has not yet been identified, a combination of markers are required for a reliable quantification of CSCs (11).

Through the assessment of CD133 expression, Eramo et al (34) managed to identify CD133-positive lung CSCs in primary human lung cancer specimens (11). These CD133-positive cells were shown to proliferate indefinitely and to display resistance to chemotherapeutic drugs. Hilbe et al (35) suggested that CD133-positive progenitor cells may play a role in NSCLC tumor vasculogenesis.

Several studies have investigated the potential clinical impact of lung CSC markers (11). The identification of new CSC biomarkers for diagnosis and treatment would be crucial for a better understanding of lung CSCs.

\section{Chemical mediators and transcription factors in EMT}

The molecular markers involved in EMT help to distinguish an epithelial cell from a mesenchymal cell. Cells undergoing EMT typically show an increase in the protein abundance of vimentin, $\mathrm{N}$-cadherin, fibronectin, and a decrease in E-cadherin, cytokeratins and occludin (36).

Early molecular signs of EMT involve the dissociation of cell-cell junctions induced by downregulation or disassembly of junctional components, such as occludins, ZO-1, claudins and E-cadherin $(2,4)$. Loss of E-cadherin expression is considered to be a hallmark of EMT (11). This loss is followed by 
Table I. Transcription factors related with EMT of lung cancer.

\begin{tabular}{|c|c|c|c|}
\hline Transcription factors & Related signaling pathways & Downregulated products & Upregulated products \\
\hline Snail & $\begin{array}{l}\text { Smad } 2 / 3 \text { (TGF- } \beta 1), \beta \text {-catenin (Wnt), } \\
\text { Notch, AKT (PI3K), NF- } \kappa \mathrm{B}, \\
\text { integrin, EGF, FGF }\end{array}$ & $\begin{array}{l}\text { E-cadherin, claudins, occludin, } \\
\text { cytokeratins, desmoplakin }\end{array}$ & $\begin{array}{l}\text { Fibronectin, N-cadherin, } \\
\text { collagen, MMPs, } \\
\text { TWIST, ZEB }\end{array}$ \\
\hline Slug & Integrin, EGF, FGF & $\begin{array}{l}\text { E-cadherin, cytokeratin, } \\
\text { desmoplakin, MUC-1 }\end{array}$ & Fibronectin, vimentin \\
\hline Twist & MAPK, NF-кB & $\begin{array}{l}\text { E-cadherin, claudins, occludin, } \\
\text { desmoplakin, plakoglobin }\end{array}$ & $\begin{array}{l}\text { Fibronectin, } \mathrm{N} \text {-cadherin, } \\
\alpha 5 \text {, integrin }\end{array}$ \\
\hline ZEB & $\begin{array}{l}\text { Smad } 2 / 3 \text { (TGF- } \beta 1), \beta \text {-catenin (Wnt), } \\
\text { RAS-MAPK }\end{array}$ & $\begin{array}{l}\text { E-cadherin, ZO1, } \\
\text { Crumbs3, plakophilin }\end{array}$ & $\begin{array}{l}\text { Collagen, SMA, fibronectin, } \\
\text { N-cadherin, MMPs }\end{array}$ \\
\hline
\end{tabular}

EMT, epithelial-mesenchymal transition; EGF, epidermal growth factor; FGF, fibroblast growth factor; MMPs, metalloproteinases.

upregulation of several mesenchymal markers, which is associated with an increased invasive potential (37). The regulators involving mesenchymal differentiation, such as Snail and Twist, are considered to regulate the EMT-induced decrease in E-cadherin expression $(38,39)$.

Vimentin is a widely expressed protein that is constitutively expressed in mesenchymal cells, including endothelial cells, macrophages, neutrophils, fibroblasts and leukocytes $(40,41)$. Vimentin is a typical marker of EMT by which epithelial cells acquire a mesenchymal phenotype that causes them to alter their shape and motility (42). In normal lung tissue, vimentin expression is restricted to the basal and columnar cells of the bronchial epithelium (43). However, in lung cancer, increased vimentin expression is associated with epithelial-derived tumor cells (44), and is used as a diagnostic marker for invasive and metastatic tumor cells $(45,46)$.

Other cytoskeletal changes involve the expression of fibroblast-specific protein (FSP) in the bronchial epithelium, which is associated with a more invasive phenotype and worse prognosis in lung cancer (47).

The Notch signaling pathway participates in the establishment of motile and invasive mesenchymal phenotypes from polarized epithelial properties, involving downregulation of epithelial markers and upregulation of mesenchymal markers $(48,49)$. The involvement of Notch signaling in lung cancer was experimentally confirmed in a transgenic mouse model (50). Clinical studies have observed that Notch signaling impacts survival in lung cancer patients (51). A recent study by Donnem et al assessed the prognostic impact of Notch ligands and receptors in NSCLC and found that high Notch expression was statistically associated with poor outcomes in lung adenocarcinoma patients (52).

TGF- $\beta 1$, a ubiquitous cytokine with profound growth inhibitory effects on epithelial and other tissues, orchestrates an intricate signaling network that is crucial to determine cell differentiation and proliferation, leading to not only tumor suppression but also EMT related with tumor invasion (53). TGF- $\beta 1$ mediates the interaction of Smad to the promoters of Snail, contributing to the development of EMT in NSCLC $(54,55)$. This could be blocked by pharmacological inactivation of Notch, indicating the key role of
Notch signaling in TGF- $\beta$-induced EMT (56). Meanwhile, inhibition of Notch signaling significantly inhibited TGF- $\beta 1$ induced expression of SMA, suggesting that Notch induces EMT through a TGF- $\beta 1-S m a d$ pathway that activates SMA gene transcription (57).

It is well established that during the physiological repair process after injury, loosening of epithelial-epithelial cell contacts, alteration of cell-extracellular matrix contacts, and morphological changes occur during wound repair (58). These phenotypic changes are thought to be mediated by EMT transcription factors (59). Key transcription factors driving EMT in lung cancer include Snail, Slug, Twist and ZEB family (Table I), which are repressors of E-cadherin transcription.

Aberrant expression of Snail expression has been noted in lung cancer (60). Strong Snail expression is observed at the leading edges of squamous cell carcinomas with loss of E-cadherin expression, suggesting a role for Snail in migration and invasion (60). Heinrich et al (17) demonstrated that Snail overexpression contributed to an increase in tumor size and metastasis.

The ZEB family (ZEB1 and ZEB2), another group of transcription factors, contributes to EMT in lung cancer $(61,62)$. Immunohistochemical study revealed that ZEB1 and Twist are commonly expressed in lung tumors (63). Downregulation of claudin 1 by Snail and Slug has been observed of lung cancer in EMT $(64,65)$.

The transcriptional repressors of E-cadherin can be regulated by hypoxia in lung cancer (17). Hypoxia-inducible factor-1 (HIF-1), a major regulator of the cellular response to hypoxia, has been shown to regulate vimentin gene expression (66). Therefore, vimentin transcriptional regulation by HIF-1 may be a potential driver of EMT in lung cancer (42).

The expression of CSC-associated transcription factors could provide prognostic information of lung cancers (11). Among them, Bmi-1 has been shown to sustain stem cell properties in normal and cancerous lung tissues $(67,68)$. An increased expression of Oct4 and Nanog was found to be associated with a worse prognosis in lung adenocarcinoma patients (69). Thyroid transcription factor-1 (TTF-1) is a transcription factor that is expressed in $\sim 75 \%$ of lung 
adenocarcinomas (3). Loss of expression of TTF-1 was observed to facilitate the generation of EMT by tumor cells resulting in a worse prognosis of patients.

Mani et al (32) demonstrated that immortalized human mammary epithelial cells induced to undergo EMT acquired expression of stem cell markers. Differentiated mammary epithelial cells that had undergone EMT via TGF- $\beta 1$ treatment or ectopic overexpression of Snail or Twist gave rise to CD44 ${ }^{+} \mathrm{CD} 244^{-}$cells with tumor-initiating capacity (17). More recently, LBX1, which directs expression of Snail, Zeb1 and Zeb2, was also noted to expand the CD44 ${ }^{+} \mathrm{CD} 24^{-} \mathrm{CSC}$ subpopulation and to morphologically transform mammary epithelial cells (70).

\section{Epigenetics and regulatory transcription factors}

Recently, researchers have focused their attention on the roles of epigenetic regulation in the EMT process due to the hypothesis that epigenetic alterations have important influences on tumorigenesis (71). Histone acetylation, microRNA (miRNA), and DNA methylation refer to three major epigenetic modifications contributing to tumorigenesis including EMT and cancer metastasis $(72,73)$.

Aberrations of any of the three major histone proteins, HATs, HDACs and histone readers, have been demonstrated to be closely correlated with lung cancer (74). The microenvironment, such as hypoxia, is demonstrated to be correlated with histone acetylation which consequently affects the EMT process (74). Increasing evidence suggests that histone acetylation/deacetylation may regulate E-cadherin during EMT in several types of cancers, including lung cancer (75). The understanding of the mechanisms of histone acetylation and its interaction with other epigenetic modifications in EMT may provide the means by which to develop potential therapeutic strategies with higher efficiency and fewer side-effects (74).

miRNAs are a class of small non-coding RNAs that negatively regulate gene expression by binding to homologous regions in target mRNAs inducing mRNA degradation (76,77). miRNAs play important roles in essential cellular processes including cell growth, differentiation, apoptosis and immune response (17). miRNAs serve as key administrators of posttranscriptional regulation and participate in EMT (78). Aberrant expression of various miRNAs is related to tumor growth and metastasis $(79,80)$.

One of the first characterized miRNA families relevant in carcinogenesis was the miR-17-92 cluster (81). It has been demonstrated that miR-17-92 cluster expression is upregulated by the proto-oncogene, c-myc, which itself is commonly dysregulated in human malignancies (82). Among other c-myc-induced miRNAs are miR-221 and miR-222, which target proteins involved in cell cycle arrest (82). miR-9 suppresses E-cadherin expression and promotes metastasis (17). Overall, the c-myc-induced miRNA network is reported to be directly related to tumor aggressiveness in various types of cancers (83).

miR-10b initiates the development of distant metastasis (84). miR-21 and miR-31 have been identified as TGF- $\beta$-dependent positive regulators of tumor cell migration, invasion and metastasis (17). High levels of miR-21 have been found in lung cancer, and its target network includes tumor suppressive components of the $\mathrm{p} 53$, TGF- $\beta$ and mitochondrial apoptosis pathways (85).

miR-200 family members are downregulated during the EMT process $(86,87)$, which in turn leads to upregulated expression of several key target genes (88). The most notable example being the regulation of Zeb1/2 by the miR-200 family, where loss of miR-200 leads to EMT $(78,89,90)$. Other miRNAs that regulate Zeb1/2 include miR-205 and miR-192/215 (89,91). miRNAs that regulate Snail1/2 include miR-1, miR-29b, miR-30c, miR-34 and miR-203 (92).

The role of EMT mediators in the regulation of miRNAs is just beginning to be revealed (17). Transcriptional repressors, such as Snail, Slug and Twist that are induced by inflammation are involved in this regulation (17). For example, Snail is able to upregulate miR-661 increasing the metastatic potential of breast cancer cells (93). Twist upregulates a positive regulator of cancer cell migration and invasion.

In recent years, miRNA studies have demonstrated that miRNAs implicated in EMT may serve as diagnostic and prognostic markers for various types of cancer (94). Further studies are needed to define the detailed mechanisms to verify the role of individual miRNAs in lung cancer. This may allow the development of novel therapeutic strategies targeting oncogenic miRNAs in lung cancer.

\section{Invasion and metastasis}

EMT is largely thought to play an important role in invasion and metastasis. EMT may enable cancer cells to lose their cell polarity and cell-cell adhesive interactions, allowing the cells to escape from the primary tumor (95). Cancer cells, that have acquired mesenchymal characteristics, can more effectively invade surrounding tissues and migrate to distant sites. Since tumor metastasis is the main obstacle for long-term survival, identification of molecular markers related to metastasis may predict the prognosis of patients with lung cancer (3). Increased E-cadherin expression was found to markedly decreased the invasion/migration of tumor cells (96). In contrast, the upregulation of $\mathrm{N}$-cadherin expression is linked to the metastasis of NSCLC (97).

The association between EMT and metastasis comes from clinical observations that distant metastasis derived from a variety of primary carcinomas resemble an epithelial phenotype (98). For example, metastases in distal organs derived from a variety of primary types of tumors exhibit overt epithelial phenotypes $(99,100)$. These observations raise the possibility that tumor cells may disseminate without switching to a mesenchymal phenotype, thereby providing controversy to the requirement of EMT for metastasis formation (98). In contrast, if cancer cells must undergo EMT to disseminate, an important question is why the resulting metastases closely resemble, at the histopathologic level, the primary carcinomas from which they have originated (98). This question has led to the possibility that the disseminated mesenchymal tumor cells recruited to target organs may undergo a reverse phenotypic transition from a mesenchymal back to an epithelial phenotype by a process called mesenchymal-to-epithelial transition (MET) (98). Xue et al (101) reported that disseminated breast tumor cells expressed mesenchymal marker Fsp-1, suggesting that EMT had occurred, which could shift back to 
an Fsp-1-negative phenotype, suggesting MET. This finding suggests that cancer cells may undergo MET in the secondary metastatic organ (98). E-cadherin was expressed at a higher level in metastatic lesions in the brain from the primary lung cancer (100). These results indicate that EMT occurs during lung carcinogenesis as well as the inverse process MET in metastatic sites (74).

Numerous strategies are being explored to develop noninvasive methods by which to detect cancer (17). These include investigations into the detection of circulating cancer cells, as well as identifying biomarkers in bronchial, oral or nasal samples (17). Profiling serum-based miRNAs is also under investigation and shows promise in identifying cancer patients vs. non-cancer individuals $(102,103)$. miRNAs, particularly the miR-200 family, have been implicated in EMT/MET transitions in cancer (104). miR-200c was found to inhibit EMT and induce an epithelial phenotype (105). In lung cancer, the number of circulating tumor cells (CTCs) expressing epithelial marker EpCAM was found to be lower compared with the number in other solid tumors (106). However, when CTC isolation is not based on epithelial markers, the CTC numbers are similar to those of other solid tumors and have strong prognostic value (107). These data suggest that lung cancer CTCs lose their epithelial characteristics having undergone EMT (108).

\section{Future target therapy and conclusion}

EMT has also been related to therapy resistance in cancer, with both preclinical and clinical evidence (95). Therapeutic refractory lung cancer cells frequently reveal an EMT phenotype, and signaling to block EMT has been shown to enhance chemotherapy sensitivity $(109,110)$. Taken together, EMT, metastasis and drug resistance are intertwined in lung cancer, and lead to aggressiveness and poor prognosis (51).

Although the underlying mechanisms have been studied for many years, the overall survival rates have not been significantly improved for patients receiving targeted therapy as compared with chemotherapy $(111,112)$. Currently, the major therapeutic obstacles are tumor recurrence and metastasis even after surgical resection, which are the main causes of mortality (74) in lung cancer patients. Studies concerning the molecular biology of EMT have elucidated the processes of invasion and metastasis, and it is expected that these basic biological findings can be eventually translated into new therapeutic approaches (95).

Receptor-specific approaches such as monoclonal antibodies or siRNAs directed against Notch may be useful in reducing the tumorigenicity and invasiveness of lung cancer (113). For instance, nanoparticle (NP) technology has been applied to deliver specific siRNAs to knock down Notch1 to arrest tumor growth and reverse EMT by the upregulation of miR-200 and downregulation of the transcription factors ZEB1, ZEB2, Snail and Slug (114).

Intermediate filaments (IFs) are an attractive potential therapeutic target for lung cancer, due to their involvement in cellular motility, transcriptional regulation, and association with EMT and tumor metastasis (42). Vimentin may be a key regulator of several tumorigenic pathways, as it forms a complex that may prevent the dephosphorylation of proteins in the complex, inhibiting antitumor activity within tumor cells (42). Furthermore, inhibition of vimentin expression by RNA interference has been shown to reduce metastatic cell invasiveness and decrease tumor volume (115).

As Wnt signaling pathways have been shown to be important in the pathogenesis of lung cancer (116), they could serve as another promising therapeutic target. At present, there are multiple therapeutic approaches targeting Wnt signaling in lung cancer which may be applied in the near future $(117,118)$.

Since CSCs share several stem-like characteristics with normal stem cells, targeted CSC therapies should be designed to preserve normal stem cells and to 'hit' only CSC-specific signaling pathways (119). The final aim is to develop a CSC-targeted therapy that will result in the complete elimination of CSCs. Presumably, this could be achieved through the disruption of signaling pathways that control the self-renewal, proliferation and differentiation of CSCs (11). Since most studies on the therapeutic efficacy of CSC targeting drugs are still in their early phases, more information must be gathered to verify the clinical importance of these drugs (11).

In conclusion, much research has highlighted the involvement of EMT in lung cancer. The precise clinical importance of the association of EMT and tumor invasion/metastasis, chemoresistance of tumor cells, de novo generation of CSCs, and tumor microenvironment remains to be determined. However, the development of drugs that target chemical mediators known to promote EMT suggest that regulation of EMT processes in the clinical setting may be possible. We anticipate the identification of novel molecular targets to facilitate the development of therapeutic agents for lung cancer as the relationships between EMT, tumor microenvironment, and CSCs are further explored in the near future.

\section{Acknowledgements}

The present study was supported by a grant from Xavier, Catholic University of Daegu (2015).

\section{References}

1. Xiao D and He J: Epithelial mesenchymal transition and lung cancer. J Thorac Dis 2: 154-159, 2010.

2. Kalluri R and Weinberg RA: The basics of epithelial-mesenchymal transition. J Clin Invest 119: 1420-1428, 2009.

3. Shi Y, Wu H, Zhang M, Ding L, Meng F and Fan X: Expression of the epithelial-mesenchymal transition-related proteins and their clinical significance in lung adenocarcinoma. Diagn Pathol 8: 89, 2013.

4. Gupta GP and Massagué J: Cancer metastasis: Building a framework. Cell 127: 679-695, 2006.

5. Lee JM, Dedhar S, Kalluri R and Thompson EW: The epithelialmesenchymal transition: New insights in signaling, development, and disease. J Cell Biol 172: 973-981, 2006.

6. Klymkowsky MW and Savagner P: Epithelial-mesenchymal transition: A cancer researcher's conceptual friend and foe. Am J Pathol 174: 1588-1593, 2009.

7. Morel AP, Lièvre M, Thomas C, Hinkal G, Ansieau S and Puisieux A: Generation of breast cancer stem cells through epithelial-mesenchymal transition. PLoS One 3: e2888, 2008

8. Battula VL, Evans KW,Hollier BG, et al: Epithelial-mesenchymal transition-derived cells exhibit multilineage differentiation potential similar to mesenchymal stem cells. Stem Cells 28: 1435-1445, 2010.

9. Thiery JP, Acloque H, Huang RY and Nieto MA: Epithelialmesenchymal transitions in development and disease. Cell 139: 871-890, 2009. 
10. Shien K, Toyooka S, Yamamoto H, Soh J, Jida M, Thu KL, Hashida S, Maki Y, Ichihara E, Asano H, et al: Acquired resistance to EGFR inhibitors is associated with a manifestation of stem cell-like properties in cancer cells. Cancer Res 73: 3051-3061, 2013

11. Koren A, Motaln H and Cufer T: Lung cancer stem cells: A biological and clinical perspective. Cell Oncol 36: 265-275, 2013

12. Kim CF, Jackson EL, Woolfenden AE, Lawrence S, Babar I, Vogel S, Crowley D, Bronson RT and Jacks T: Identification of bronchioalveolar stem cells in normal lung and lung cancer. Cell 121: 823-835, 2005.

13. Willis BC and Borok Z: TGF-beta-induced EMT: Mechanisms and implications for fibrotic lung disease. Am J Physiol Lung Cell Mol Physiol 293: L525-L534, 2007.

14. Wu Y, Deng J, Rychahou PG, Qiu S, Evers BM and Zhou BP: Stabilization of snail by NF-kappaB is required for inflammationinduced cell migration and invasion. Cancer Cell 15: 416-428, 2009.

15. De Wever O and Mareel M: Role of tissue stroma in cancer cell invasion. J Pathol 200: 429-447, 2003.

16. Kalluri $\mathrm{R}$ and Zeisberg M: Fibroblasts in cancer. Nat Rev Cancer 6: 392-401, 2006.

17. Heinrich EL, Walser TC, Krysan K, Liclican EL, Grant JL, Rodriguez NL and Dubinett SM: The inflammatory tumor microenvironment, epithelial mesenchymal transition and lung carcinogenesis. Cancer Microenviron 5: 5-18, 2012.

18. Nizet V and Johnson RS: Interdependence of hypoxic and innate immune responses. Nat Rev Immunol 9: 609-617, 2009.

19. Fitzpatrick SF, Tambuwala MM, Bruning U, Schaible B, Scholz CC, Byrne A, O'Connor A, Gallagher WM, Lenihan CR, Garvey JF, et al: An intact canonical NF- $\kappa \mathrm{B}$ pathway is required for inflammatory gene expression in response to hypoxia. J Immunol 186: 1091-1096, 2011.

20. Semenza GL: Defining the role of hypoxia-inducible factor 1 in cancer biology and therapeutics. Oncogene 29: 625-634, 2010.

21. Harris AL: Hypoxia - a key regulatory factor in tumour growth Nat Rev Cancer 2: 38-47, 2002.

22. Giatromanolaki A, Sivridis E and Koukourakis MI: The pathology of tumor stromatogenesis. Cancer Biol Ther 6: 639-645, 2007.

23. Bonde AK, Tischler V, Kumar S, Soltermann A and Schwendener RA: Intratumoral macrophages contribute to epithelial-mesenchymal transition in solid tumors. BMC Cancer 12: 35, 2012.

24. Reya T, Morrison SJ, Clarke MF and Weissman IL: Stem cells, cancer, and cancer stem cells. Nature 414: 105-111, 2001.

25. Liu WH, You N, Zhang N, Yan HT, Wang T, Huang Z, Liu HB and Tang LJ: Interpretation of interlocking key issues of cancer stem cells in malignant solid tumors. Cell Oncol 35: 397-409, 2012.

26. Visvader JE and Lindeman GJ: Cancer stem cells in solid tumours: Accumulating evidence and unresolved questions. Nat Rev Cancer 8: 755-768, 2008.

27. Hanahan D and Weinberg RA: Hallmarks of cancer: The next generation. Cell 144: 646-674, 2011.

28. Sullivan JP, Minna JD and Shay JW: Evidence for self-renewing lung cancer stem cells and their implications in tumor initiation, progression, and targeted therapy. Cancer Metastasis Rev 29: 61-72, 2010.

29. Kitamura H, Okudela K, Yazawa T, Sato H and Shimoyamada H: Cancer stem cell: Implications in cancer biology and therapy with special reference to lung cancer. Lung Cancer 66: 275-281, 2009.

30. Sullivan JP, Spinola M, Dodge M, Raso MG, Behrens C, Gao B, Schuster K, Shao C, Larsen JE, Sullivan LA, et al: Aldehyde dehydrogenase activity selects for lung adenocarcinoma stem cells dependent on notch signaling. Cancer Res 70: 9937-9948, 2010.

31. Al-Hajj M, Wicha MS, Benito-Hernandez A, Morrison SJ and Clarke MF: Prospective identification of tumorigenic breast cancer cells. Proc Natl Acad Sci USA 100: 3983-3988, 2003.

32. Mani SA, Guo W, Liao MJ, Eaton EN, Ayyanan A, Zhou AY, Brooks M, Reinhard F, Zhang CC, Shipitsin M, et al: The epithelial-mesenchymal transition generates cells with properties of stem cells. Cell 133: 704-715, 2008

33. Leung EL, Fiscus RR, Tung JW, Tin VP, Cheng LC, Sihoe AD, Fink LM, Ma Y and Wong MP: Non-small cell lung cancer cells expressing CD44 are enriched for stem cell-like properties. PLoS One 5: e14062, 2010.
34. Eramo A, Lotti F, Sette G, Pilozzi E, Biffoni M, Di Virgilio A, Conticello C, Ruco L, Peschle C and De Maria R: Identification and expansion of the tumorigenic lung cancer stem cell population. Cell Death Differ 15: 504-514, 2008.

35. Hilbe W, Dirnhofer S, Oberwasserlechner F, Schmid T, Gunsilius E, Hilbe G, Wöll E and Kähler CM: CD133 positive endothelial progenitor cells contribute to the tumour vasculature in non-small cell lung cancer. J Clin Pathol 57: 965-969, 2004.

36. Weber CE, Li NY, Wai PY and Kuo PC: Epithelial-mesenchymal transition, TGF- $\beta$, and osteopontin in wound healing and tissue remodeling after injury. J Burn Care Res 33: 311-318, 2012.

37. Thiery JP and Sleeman JP: Complex networks orchestrate epithelial-mesenchymal transitions. Nat Rev Mol Cell Biol 7: 131-142, 2006.

38. Castro Alves C, Rosivatz E, Schott C, Hollweck R, Becker I, Sarbia M, Carneiro F and Becker KF: Slug is overexpressed in gastric carcinomas and may act synergistically with SIP1 and Snail in the down-regulation of E-cadherin. J Pathol 211: 507-515, 2007.

39. Aamodt R, Bondi J, Andersen SN, Bakka A, Bukholm G and Bukholm IR: The prognostic impact of protein expression of E-cadherin-catenin complexes differs between rectal and colon carcinoma. Gastroenterol Res Pract 2010: 616-623, 2010.

40. Satelli A and Li S: Vimentin in cancer and its potential as a molecular target for cancer therapy. Cell Mol Life Sci 68: 3033-3046, 2011.

41. Crystal RG, Randell SH, Engelhardt JF, Voynow J and Sunday ME: Airway epithelial cells: Current concepts and challenges. Proc Am Thorac Soc 5: 772-777, 2008.

42. Kidd ME, Shumaker DK and Ridge KM: The role of vimentin intermediate filaments in the progression of lung cancer. Am J Respir Cell Mol Biol 50: 1-6, 2014.

43. Schoumacher M, Goldman RD, Louvard D and Vignjevic DM: Actin, microtubules, and vimentin intermediate filaments cooperate for elongation of invadopodia. J Cell Biol 189: 541-556, 2010.

44. Helfand BT, Mendez MG, Murthy SN, Shumaker DK, Grin B, Mahammad S, Aebi U, Wedig T, Wu YI, Hahn KM, et al: Vimentin organization modulates the formation of lamellipodia. Mol Biol Cell 22: 1274-1289, 2011.

45. Geiger TR and Peeper DS: Metastasis mechanisms. Biochim Biophys Acta 1796: 293-308, 2009.

46. Gilles C, Polette M, Zahm JM, Tournier JM, Volders L, Foidart JM and Birembaut P: Vimentin contributes to human mammary epithelial cell migration. J Cell Sci 112: 4615-4625, 1999.

47. Kimura K, Endo Y, Yonemura Y, Heizmann CW, Schafer BW, Watanabe Y and Sasaki T: Clinical significance of S100A4 and E-cadherin-related adhesion molecules in non-small cell lung cancer. Int J Oncol 16: 1125-1131, 2000.

48. De Craene B and Berx G: Regulatory networks defining EMT during cancer initiation and progression. Nat Rev Cancer 13: 97-110, 2013

49. Chang AC, Garside VC, Fournier M, Smrz J, Vrljicak P, Umlandt P, Fuller M, Robertson G, Zhao Y, Tam A, et al: A Notch-dependent transcriptional hierarchy promotes mesenchymal transdifferentiation in the cardiac cushion. Dev Dyn 243: 894-905, 2014.

50. Allen TD, Rodriguez EM, Jones KD and Bishop JM: Activated Notch1 induces lung adenomas in mice and cooperates with Myc in the generation of lung adenocarcinoma. Cancer Res 71: 6010-6018, 2011

51. Yuan X, Wu H, Han N, Xu H, Chu Q, Yu S, Chen Y and Wu K: Notch signaling and EMT in non-small cell lung cancer: Biological significance and therapeutic application. J Hematol Oncol 7: 87-96, 2014.

52. Donnem T, Andersen S, Al-Shibli K, Al-Saad S, Busund LT and Bremnes RM: Prognostic impact of Notch ligands and receptors in nonsmall cell lung cancer: Coexpression of Notch-1 and vascular endothelial growth factor-A predicts poor survival. Cancer 116: 5676-5685, 2010.

53. Zavadil J and Böttinger EP: TGF-beta and epithelial-to-mesenchymal transitions. Oncogene 24: 5764-5774, 2005.

54. Lin LC, Hsu SL, Wu CL and Hsueh CM: TGF $\beta$ can stimulate the $\mathrm{p} 38 / \beta$-catenin/PPAR $\gamma$ signaling pathway to promote the EMT, invasion and migration of non-small cell lung cancer $(\mathrm{H} 460$ cells). Clin Exp Metastasis 31: 881-895, 2014. 
55. Zhang HJ, Wang HY, Zhang HT, Su JM, Zhu J, Wang HB, Zhou WY, Zhang H, Zhao MC, Zhang L, et al: Transforming growth factor- $\beta 1$ promotes lung adenocarcinoma invasion and metastasis by epithelial-to-mesenchymal transition. Mol Cell Biochem 355: 309-314, 2011.

56. Zavadil J, Cermak L, Soto-Nieves N and Böttinger EP: Integration of TGF-beta/Smad and Jagged1/Notch signalling in epithelial-to-mesenchymal transition. EMBO J 23: 1155-1165, 2004.

57. Matsuno Y, Coelho AL, Jarai G, Westwick J and Hogaboam CM: Notch signaling mediates TGF- $\beta 1$-induced epithelial-mesenchymal transition through the induction of Snail. Int J Biochem Cell Biol 44: 776-789, 2012.

58. Vaughan AE and Chapman HA: Regenerative activity of the lung after epithelial injury. Biochim Biophys Acta 1832: 922-930, 2013.

59. Savagner P, Kusewitt DF, Carver EA, Magnino F, Choi C, Gridley $\mathrm{T}$ and Hudson LG: Developmental transcription factor slug is required for effective re-epithelialization by adult keratinocytes. J Cell Physiol 202: 858-866, 2005.

60. Yanagawa J, Walser TC, Zhu LX, Hong L, Fishbein MC, Mah V, Chia D, Goodglick L, Elashoff DA, Luo J, et al: Snail promotes CXCR2 ligand-dependent tumor progression in non-small cell lung carcinoma. Clin Cancer Res 15: 6820-6829, 2009.

61. Yang Y, Ahn YH, Chen Y, Tan X, Guo L, Gibbons DL, Ungewiss C, Peng DH, Liu X, Lin SH, et al: ZEB1 sensitizes lung adenocarcinoma to metastasis suppression by PI3K antagonism. J Clin Invest 124: 2696-2708, 2014.

62. Argast GM, Krueger JS, Thomson S, Sujka-Kwok I, Carey K, Silva S, O'Connor M, Mercado P, Mulford IJ, Young GD, et al: Inducible expression of TGF $\beta$, snail and Zeb1 recapitulates EMT in vitro and in vivo in a NSCLC model. Clin Exp Metastasis 28: 593-614, 2011.

63. Merikallio H, Kaarteenaho R, Pääkkö P, Lehtonen S, Hirvikoski P, Mäkitaro R, Harju T and Soini Y: Zeb1 and twist are more commonly expressed in metastatic than primary lung tumours and show inverse associations with claudins. J Clin Pathol 64: 136-140, 2011.

64. Kojima T, Takano K, Yamamoto T, Murata M, Son S, Imamura M, Yamaguchi H, Osanai M, Chiba H, Himi T, et al: Transforming growth factor-beta induces epithelial to mesenchymal transition by down-regulation of claudin-1 expression and the fence function in adult rat hepatocytes. Liver Int 28: 534-545, 2008.

65. Martínez-Estrada OM, Cullerés A, Soriano FX, Peinado H, Bolós V, Martínez FO, Reina M, Cano A, Fabre M and Vilaró S: The transcription factors Slug and Snail act as repressors of Claudin-1 expression in epithelial cells. Biochem J 394: 449-457, 2006.

66. Krishnamachary B, Berg-Dixon S, Kelly B, Agani F, Feldser D, Ferreira G, Iyer N, LaRusch J, Pak B, Taghavi P, et al: Regulation of colon carcinoma cell invasion by hypoxia-inducible factor 1 . Cancer Res 63: 1138-1143, 2003.

67. Dovey JS, Zacharek SJ, Kim CF and Lees JA: Bmil is critical for lung tumorigenesis and bronchioalveolar stem cell expansion. Proc Natl Acad Sci USA 105: 11857-11862, 2008.

68. Wu KJ: Direct activation of Bmi1 by Twist1: Implications in cancer stemness, epithelial-mesenchymal transition, and clinical significance. Chang Gung Med J 34: 229-238, 2011.

69. Chiou SH, Wang ML, Chou YT, Chen CJ, Hong CF, Hsieh WJ, Chang HT, Chen YS, Lin TW, Hsu HS, et al: Coexpression of Oct4 and Nanog enhances malignancy in lung adenocarcinoma by inducing cancer stem cell-like properties and epithelialmesenchymal transdifferentiation. Cancer Res 70: 10433-10444, 2010.

70. Yu M, Smolen GA, Zhang J, Wittner B, Schott BJ, Brachtel E, Ramaswamy S, Maheswaran S and Haber DA: A developmentally regulated inducer of EMT, LBX1, contributes to breast cancer progression. Genes Dev 23: 1737-1742, 2009.

71. Sandoval J and Esteller M: Cancer epigenomics: Beyond genomics. Curr Opin Genet Dev 22: 50 55, 2012.

72. Micalizzi DS, Farabaugh SM and Ford HL: Epithelialmesenchymal transition in cancer: Parallels between normal development and tumor progression. J Mammary Gland Biol Neoplasia 15: 117-134, 2010.

73. Giudice FS, Pinto DS Jr, Nör JE, Squarize CH and Castilho RM Inhibition of histone deacetylase impacts cancer stem cells and induces epithelial-mesenchyme transition of head and neck cancer. PLoS One 8: e58672, 2013.
74. Zhang L, Liu Z, Ma W and Wang B: The landscape of histone acetylation involved in epithelial-mesenchymal transition in lung cancer. J Cancer Res Ther 9 (Suppl 2): S86-S91, 2013.

75. Wang Y and Shang Y: Epigenetic control of epithelial-to-mesenchymal transition and cancer metastasis. Exp Cell Res 319: 160-169, 2013.

76. Fire A, Xu S, Montgomery MK, Kostas SA, Driver SE and Mello CC: Potent and specific genetic interference by doublestranded RNA in Caenorhabditis elegans. Nature 391: 806-811, 1998.

77. He L and Hannon GJ: MicroRNAs: Small RNAs with a big role in gene regulation. Nat Rev Genet 5: 522-531, 2004.

78. Gibbons DL, Lin W, Creighton CJ, Rizvi ZH, Gregory PA, Goodall GJ, Thilaganathan N, Du L, Zhang Y, Pertsemlidis A, et al: Contextual extracellular cues promote tumor cell EMT and metastasis by regulating miR-200 family expression. Genes Dev 23: 2140-2151, 2009.

79. Ma L, Young J, Prabhala H, Pan E, Mestdagh P, Muth D, Teruya-Feldstein J, Reinhardt F, Onder TT, Valastyan S, et al: miR 9, a MYC/MYCN activated microRNA, regulates E cadherin and cancer metastasis. Nat Cell Biol 12: 247 256, 2010.

80. Valastyan S, Reinhardt F, Benaich N, Calogrias D, Szász AM, Wang ZC, Brock JE, Richardson AL and Weinberg RA: A pleiotropically acting microRNA, miR 31 , inhibits breast cancer metastasis. Cell 137: 1032 1046, 2009.

81. Tanzer A and Stadler PF: Molecular evolution of a microRNA cluster. J Mol Biol 339: 327-335, 2004.

82. Kim JW, Mori S and Nevins JR: Myc-induced microRNAs integrate Myc-mediated cell proliferation and cell fate. Cancer Res 70: 4820-4828, 2010.

83. Mestdagh P, Fredlund E, Pattyn F, Schulte JH, Muth D, Vermeulen J, Kumps C, Schlierf S, De Preter K, Van Roy N, et al: $\mathrm{MYCN} / \mathrm{c}-\mathrm{MYC}$-induced microRNAs repress coding gene networks associated with poor outcome in MYCN/c-MYCactivated tumors. Oncogene 29: 1394-1404, 2010.

84. Ma L, Teruya-Feldstein J and Weinberg RA: Tumour invasion and metastasis initiated by microRNA-10b in breast cancer. Nature 449: 682-688, 2007.

85. Schramedei K, Mörbt N, Pfeifer G, Läuter J, Rosolowski M, Tomm JM, von Bergen $\mathrm{M}$, Horn $\mathrm{F}$ and Brocke-Heidrich $\mathrm{K}$ : MicroRNA-21 targets tumor suppressor genes ANP32A and SMARCA4. Oncogene 30: 2975-2985, 2011.

86. Mongroo PS and Rustgi AK: The role of the miR-200 family in epithelial-mesenchymal transition. Cancer Biol Ther 10: 219-222, 2010.

87. Manavalan TT, Teng Y, Litchfield LM, Muluhngwi P, Al-Rayyan N and Klinge CM: Reduced expression of miR-200 family members contributes to antiestrogen resistance in LY2 human breast cancer cells. PLoS One 8: e62334, 2013.

88. Hill L, Browne $\mathrm{G}$ and Tulchinsky E: ZEB/miR-200 feedback loop: At the crossroads of signal transduction in cancer. Int J Cancer 132: 745-754, 2013.

89. Gregory PA, Bert AG, Paterson EL, Barry SC, Tsykin A, Farshid G, Vadas MA, Khew-Goodall Y and Goodall GJ: The miR-200 family and miR-205 regulate epithelial to mesenchymal transition by targeting ZEB1 and SIP1. Nat Cell Biol 10: 593-601, 2008.

90. Burk U, Schubert J, Wellner U, Schmalhofer O, Vincan E, Spaderna $S$ and Brabletz T: A reciprocal repression between ZEB1 and members of the miR-200 family promotes EMT and invasion in cancer cells. EMBO Rep 9: 582-589, 2008.

91. Wang B,Herman-Edelstein M,Koh P, Burns W,Jandeleit-Dahm K, Watson A, Saleem M, Goodall GJ, Twigg SM, Cooper ME, et al: E-cadherin expression is regulated by miR-192/215 by a mechanism that is independent of the profibrotic effects of transforming growth factor-beta. Diabetes 59: 1794-1802, 2010.

92. Lamouille S, Subramanyam D, Blelloch R and Derynck R: Regulation of epithelial-mesenchymal and mesenchymal-epithelial transitions by microRNAs. Curr Opin Cell Biol 25: 200-207, 2013.

93. Vetter G, Saumet A, Moes M, Vallar L, Le Béchec A, Laurini C, Sabbah M, Arar K, Theillet C, Lecellier CH, et al: miR-661 expression in SNAI1-induced epithelial to mesenchymal transition contributes to breast cancer cell invasion by targeting Nectin-1 and StarD10 messengers. Oncogene 29: 4436-4448, 2010.

94. Brase JC, Wuttig D, Kuner R and Sültmann H: Serum microRNAs as non-invasive biomarkers for cancer. Mol Cancer 9: 306, 2010. 
95. Creighton CJ, Gibbons DL and Kurie JM: The role of epithelial-mesenchymal transition programming in invasion and metastasis: A clinical perspective. Cancer Manag Res 5: 187-195, 2013

96. Mateen S, Raina K, Agarwal C, Chan D and Agarwal R: Silibinin synergizes with histone deacetylase and DNA methyltransferase inhibitors in upregulating E-cadherin expression together with inhibition of migration and invasion of human non-small cell lung cancer cells. J Pharmacol Exp Ther 345: 206-214, 2013.

97. Zhang X, Liu G, Kang Y, Dong Z, Qian Q and Ma X: N-cadherin expression is associated with acquisition of EMT phenotype and with enhanced invasion in erlotinib-resistant lung cancer cell lines. PLoS One 8: e57692, 2013

98. Gao D, Vahdat LT, Wong S, Chang JC and Mittal V: Microenvironmental regulation of epithelial-mesenchymal transitions in cancer. Cancer Res 72: 4883-4889, 2012.

99. Yates C: Prostate tumor cell plasticity: A consequence of the microenvironment. Adv Exp Med Biol 720: 81-90, 2011.

100. Prudkin L, Liu DD, Ozburn NC, Sun M, Behrens C, Tang X, Brown KC, Bekele BN, Moran C and Wistuba II: Epithelial-tomesenchymal transition in the development and progression of adenocarcinoma and squamous cell carcinoma of the lung. Mod Pathol 22: 668-678, 2009.

101. Xue C, Plieth D, Venkov C, Xu C and Neilson EG: The gatekeeper effect of epithelial-mesenchymal transition regulates the frequency of breast cancer metastasis. Cancer Res 63 : 3386-3394, 2003.

102. Houbaviy HB, Murray MF and Sharp PA: Embryonic stem cell-specific MicroRNAs. Dev Cell 5: 351-358, 2003.

103. Lu Y, Thomson JM, Wong HY, Hammond SM and Hogan BL: Transgenic over-expression of the microRNA miR-17-92 cluster promotes proliferation and inhibits differentiation of lung epithelial progenitor cells. Dev Biol 310: 442-453, 2007.

104. Bullock MD, Sayan AE, Packham GK and Mirnezami AH: MicroRNAs: Critical regulators of epithelial to mesenchymal (EMT) and mesenchymal to epithelial transition (MET) in cancer progression. Biol Cell 104: 3-12, 2012.

105. Korpal M, Lee ES, Hu G and Kang Y: The miR-200 family inhibits epithelial-mesenchymal transition and cancer cell migration by direct targeting of E-cadherin transcriptional repressors ZEB1 and ZEB2. J Biol Chem 283: 14910-14914, 2008.

106. Krebs MG, Sloane R, Priest L, Lancashire L, Hou JM, Greystoke A, Ward TH, Ferraldeschi R, Hughes A, Clack G, et al: Evaluation and prognostic significance of circulating tumor cells in patients with non-small-cell lung cancer. J Clin Oncol 29: 1556-1563, 2011.

107. Hofman V, Bonnetaud C, Ilie MI, Vielh P, Vignaud JM, Fléjou JF, Lantuejoul S, Piaton E, Mourad N, Butori C, et al: Preoperative circulating tumor cell detection using the isolation by size of epithelial tumor cell method for patients with lung cancer is a new prognostic biomarker. Clin Cancer Res 17: 827-835, 2011.

108. Bartis D, Mise N, Mahida RY, Eickelberg O and Thickett DR: Epithelial-mesenchymal transition in lung development and disease: Does it exist and is it important? Thorax 69: 760-765, 2014.
109. Buonato JM and Lazzara MJ: ERK1/2 blockade prevents epithelial-mesenchymal transition in lung cancer cells and promotes their sensitivity to EGFR inhibition. Cancer Res 74: 309-319, 2014.

110. Wilson C, Nicholes K, Bustos D, Lin E, Song Q, Stephan JP, Kirkpatrick DS and Settleman J: Overcoming EMT-associated resistance to anti-cancer drugs via Src/FAK pathway inhibition. Oncotarget 5: 7328-7341, 2014.

111. Fukuoka M, Wu YL, Thongprasert S, Sunpaweravong P, Leong SS, Sriuranpong V, Chao TY, Nakagawa K, Chu DT, Saijo N, et al: Biomarker analyses and final overall survival results from a phase III, randomized, open-label, first-line study of gefitinib versus carboplatin/paclitaxel in clinically selected patients with advanced non-small-cell lung cancer in Asia (IPASS). J Clin Oncol 29: 2866-2874, 2011.

112. Shaw AT, Kim DW, Nakagawa K, Seto T, Crinó L, Ahn MJ, De Pas T, Besse B, Solomon BJ, Blackhall F, et al: Crizotinib versus chemotherapy in advanced ALK-positive lung cancer. $\mathrm{N}$ Engl J Med 368: 2385-2394, 2013.

113. Li Y, Burns JA, Cheney CA, Zhang N, Vitelli S, Wang F, Bett A, Chastain M, Audoly LP and Zhang ZQ: Distinct expression profiles of Notch-1 protein in human solid tumors: Implications for development of targeted therapeutic monoclonal antibodies. Biologics 4: 163-171, 2010.

114. Sureban SM, May R, Mondalek FG, Qu D, Ponnurangam S, Pantazis P, Anant S, Ramanujam RP and Houchen CW: Nanoparticle-based delivery of siDCAMKL-1 increases microRNA-144 and inhibits colorectal cancer tumor growth via a Notch-1 dependent mechanism. J Nanobiotechnology 9: 40, 2011.

115. Paccione RJ, Miyazaki H, Patel V, Waseem A, Gutkind JS, Zehner ZE and Yeudall WA: Keratin down-regulation in vimentin-positive cancer cells is reversible by vimentin RNA interference, which inhibits growth and motility. Mol Cancer Ther 7: 2894-2903, 2008

116. Bartis D, Csongei V, Weich A, Kiss E, Barko S, Kovacs T, Avdicevic M, D'Souza VK, Rapp J, Kvell K, et al: Downregulation of canonical and up-regulation of non-canonical Wnt signalling in the carcinogenic process of squamous cell lung carcinoma. PLoS One 8: e57393, 2013.

117. Henderson WR Jr, Chi EY, Ye X, Nguyen C, Tien YT, Zhou B, Borok Z, Knight DA and Kahn M: Inhibition of Wnt/ $\beta$-catenin/CREB binding protein (CBP) signaling reverses pulmonary fibrosis. Proc Natl Acad Sci USA 107: 14309-14314, 2010.

118. Tennis MA, Van Scoyk M, Heasley LE, Vandervest K, Weiser-Evans M, Freeman S, Keith RL, Simpson P, Nemenoff RA and Winn RA: Prostacyclin inhibits non-small cell lung cancer growth by a frizzled 9-dependent pathway that is blocked by secreted frizzled-related protein 1. Neoplasia 12: 244-253, 2010

119. Eramo A, Haas TL and De Maria R: Lung cancer stem cells: Tools and targets to fight lung cancer. Oncogene 29: 4625-4635, 2010. 